70 卷 $689^{\frac{1}{*}{ }^{\prime}}(2004$ 1)

\title{
モンテカルロ法によるイオン化スパッタシミュレーション*
}

(第 1 報, $\mathrm{Cu}$ 埋め込み形状の再現)

\author{
山崎 修*1, 高木茂 行*2, 井柳 克 ${ }^{* 2}$ \\ 木下和 哉*2, 間 瀬 康一*2 \\ 八尋 和 ${ }^{* 2}$, 南 部 健一*3
}

\section{Monte Carlo Simulation of Ionization Sputtering}

(1st Report, Reproduction of Shape of Buried Cu Films)

Osamu YAMAZAKI*4, Shigeyuki TAKAGI, Katsumi IYANAGI,

Kazuya KINOSHITA, Koichi MASE,

Kazuyuki YAHIRO and Kenichi NANBU

${ }^{* 4}$ Corporate Manufacturing Engineering Center, Toshiba Corporation,

33 Shin isogo cho, Isogo ku, Yokohama-shi, Kanagawa, 235-0017 Japan

In order to fabricate fine structures, film synthesis systems with excellent burial characteristics are required. One way of improving burial characteristics is to use ionization sputtering, in which sputtered atoms are ionized in flight and are then drawn to the wafer by an applied self-bias voltage. The Monte Carlo simulation of $\mathrm{Cu}$ ionization sputtering is performed. For ionization sputtering, it is important to understand the ionization of sputtered atoms in flight. The degree of ionization is calculated from the electron density and electron temperature, which are obtained through plasma simulations, and is used in the Monte Carlo simulation. In addition, the direction of $\mathrm{Cu}$ ions bent towards the substrate due to the sheath electric field, which is determined from the plasma simulation, is also used. These simulations successfully reproduce the shape of buried $\mathrm{Cu}$ films.

Key Words : Numerical Analysis, Plasma, Rarefied Gas, Ionization Sputtering, Monte Carlo Simulation, Copper Film, Embedding Form

\section{1. 铛}

半導体の高速化や配線の微細化に伴い，配線材料と して現在の $\mathrm{Al}$ よりも低抵抗な $\mathrm{Cu}$ が注目されている (1)2).この Cu配線は，酸化膜エッチングにより配線溝 や穴を掘り，Cuメッキ後 OMP (Chemical Mechanical Polishing) を行うというダマシンプロセスにより形成 されている.このプロセスでは Cu メッキに先立ち溝 や穴の内部に膜切れの無い $\mathrm{Cu}$ シード層を形成する必 要があり，埋め込み性の良いスパッタプロセスおよび スパッタ装置の開発が求められている.

これに対し，近年イオン化スパッタが実用化されて いる. ターゲットから放出された Cu 原子を, チャン バ内部での輸送中に ICP (Inductively Coupled Plasma)に よる高密度プラズマでイオン化し， ウエハのバイアス 電圧て配線溝や穴の内部に引き込むという力法である. このような装置では, 従来に比べ $\mathrm{Cu}$ 原子の電離度や バイアス制御が加わるためプロセスの適正化が困難で あり，装置仕様も複雑となっている ${ }^{(3)(4)}$. 実験による

* 原稿曼付 2002 件. 9 川 2511 .

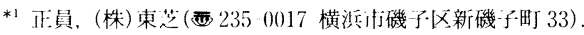

*2 (株) 東茫.

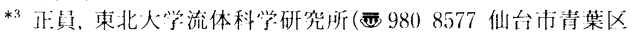
片平. 2 1 1 )

E mail : osamu(a mel.toshiba.co.jp
試行錯誤的な手法ではプロセス開発に大きなコストと 長い期間を要するため, シミュレーションの適用が求 められている.

従来のスパッタ装置のシミュレーションについては, 多くの報告がなされている ${ }^{(5)-(19)}$. また，我々はター

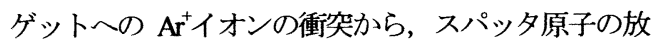
出, チャンバ内での輸送, ウエハへの付着までの過程 の一貫した報告をしてきた(17).さらに，イオン化スパ ッ夕装置に対しては, 中性粒子，イオン粒子を考慮し て形状を計算した結果が報告されている(18)(19)，しかし ながらこれらの報告はイオン化率をシミュレーショ ンにより求めておらず, パラメータとして計算してい る.このため, 現状のイオン化スパッタ装置を十分に はシミュレーション出来ていない.

そこで我々は，Ouのイオン化スパッタ装置に対し て $\mathrm{Ou}$ 原子の電離衝突断面積, チャンバ内の電子密度 と電子温度からイオン化率を求め, ターゲットからの $\mathrm{Cu}$ 原子の放出, 飛行中の原子のイオン化, イオンの シ一ス中での挙動, 表面付着を一貫して計算するシミ ュレーションモデルを初めて構築し, 実験結果との比 較によるモデル検証を行った. この結果, SEM 写真 により求めた断面形状と良い一致を見たので報告する. 


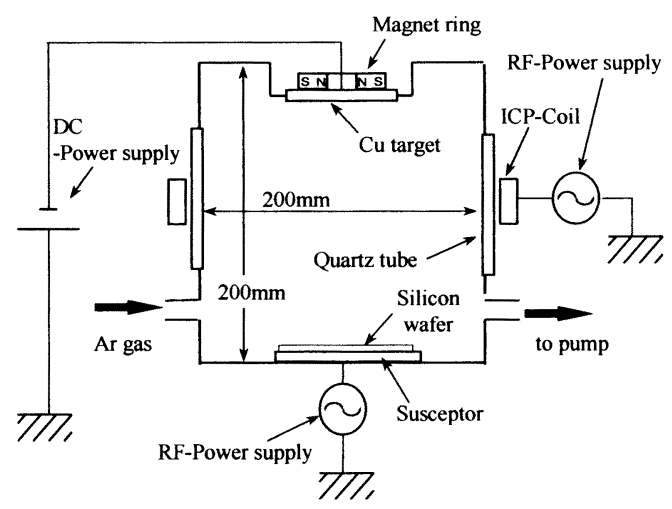

Fig.1 Experimental device composition

\section{2. 装置構成}

実験装置を図 1 に示す．ターグット上部に磁石を設 置した DC マグネトロン方式のスパッタ装置である. チャンバの形状は直径 $200 \mathrm{~mm}$ ，高さ $200 \mathrm{~mm}, の 円$ 筒形で側壁の中央部分は石英製，その他はステンレス 製である.チャンバ上部に直径 $75 \mathrm{~mm}$ の円盤 状のターゲットを設置しており，この上部には円筒状 の永久磁石が置かれている. ターゲット表面での磁束 密度は最大 $02 \mathrm{~T}$ である. チャンバ下部には, ウエハ を設置するサセプタが置かれる.

ターゲットには直流電源の負極が接続されており, チャンバ外壁の金属部分はアースされている. チャン バの周囲にはコイルが巻かれ $\mathrm{RF}$ 電源に接続されてい る. またウエハを載せたサセプタにも別の $\mathrm{RF}$ 電源が 接続されておりウエハにバイアスを与える. 各電源の パワーは, ターゲットの直流電源 : $200 \mathrm{~W}$, コイルの $\mathrm{RF}$ 電源 : $100 \mathrm{~W}$, サセプタの $\mathrm{RF}$ 電源 : $100 \mathrm{~W}$ である. チャンバ内に供給するガスは Ar, 流量は標準状態で $2.5 \mathrm{~m}^{3} / \mathrm{s}$, ガス圧力は $2.7 \mathrm{~Pa}$ とした.

\section{3. シミュレーション方法}

シミュレーションはコンタクト穴のシード層形成を 想定して行った. 計算は図2 2 流れで行う. ターゲッ トから飛び出した $\mathrm{Cu}$ 原子の挙動をテスト粒子モンテ カルロ法 ${ }^{(20) を}$ 用いて計算する. 同時にプラズマシミュ レーションを行い, チャンバ内の電子密度と電子温度 を求める. これらから計算された確率で, 飛翔中の $\mathrm{Cu}$ 原子は電離するとした. プラズマのバルク内では 電界は小さく(21)，これによる $\mathrm{Ou}^{+}$イオンの軌道の曲げ はないとした. シースに入った $\mathrm{Cu}^{+}$イオンはプラズマ

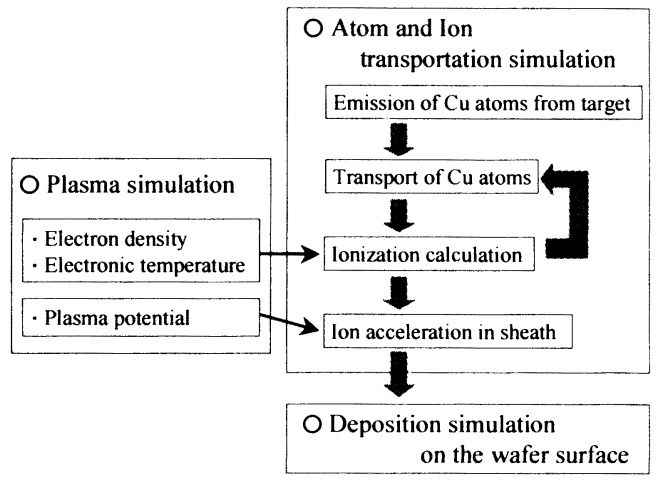

Fig.2 Simulation model

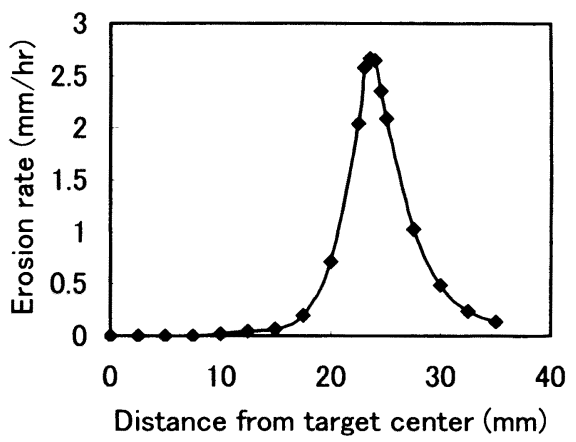

Fig.3 Target erosion

シミュレーションから求まった電界でウエハと垂直方 向に曲げられる. 最終的に, $\mathrm{Cu}$ 原子・ Cu+イオンはウ エハやチャン八壁面に付着する.この時の $\mathrm{Cu}$ の堆積 形状を求める．以下にこの手法について詳細に記述す る.

3.1 ターゲットからの Cu原子の放出 ターゲッ トから放出される粒子は $\mathrm{Cu}^{+}$イオンやクラスタも放出 されるが，大部分が $\mathrm{Cu}$ 原子であり ${ }^{(2)}$ ，今回のシミュ レーションでも $\mathrm{Cu}$ 原子のみを考虑した.ターゲット からの Cu原子の放出分布は, 図3 に示すようなエロ ージョン分布に比例するとした．放出されるCu原子 の運動エネルギーは類似の報告例(20)を参考に平均 10 $\mathrm{eV}$ のマックスウェル分布と仮定した. スパッタシミ ユレーションでは, ターゲットから放出される粒子 の運動エネルギー分布に，トンプソン分布かマック スウェル分布を使用している(5)(6). 今回の装置では ガス圧力が比較的高く, $\mathrm{Cu}$ 原子はウエハに達する まで Ar原子との衝突を繰り返すため，成膜時には 


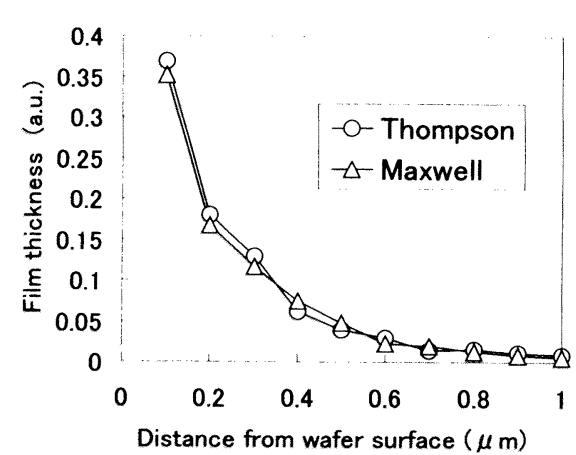

Fig.4 Tompson distribution vs. Maxwell distribution

放出時の運動エネルギーによる差は無くなると考え られる. 図 4 に，5章の図 8 で示す穴の側面への成 膜の分布を, トンプソン分布およびマックスウェル 分布で比較した結果を示す.これより両者に差が無 いことが確認できたため, 以後は計算負荷の低いマ ックスウェル分布を用いた.

さらに放出角度は余弦則に従うとした.この時の $\mathrm{Cu}$ 原子の速度ベクトル $\left(c_{x}, c_{y}, c_{z}\right)$ を以下 (1) (3) 式 に示す ${ }^{(20) .} \mathrm{z}$ 軸はターゲット表面に垂直な軸とした直 角座標系である.

$$
\begin{aligned}
& c_{z}=\left(-E_{0} \ln U / m_{C u}\right)^{1 / 2} \\
& c_{x}=c_{r} \cos \theta \\
& c_{y}=c_{r} \sin \theta
\end{aligned}
$$

ここで， $m_{C u}$ は $\mathrm{Gu}$ 原子の質量, $\theta$ は $2 \pi U$, すべ ての $U$ は独立した一様乱数, $E_{0}$ はスパッタ原子の 放出時の平均運動エネルギーで $10 \mathrm{eV}$ とした(20). また, $c_{r}$ は以下の式に従う。

$$
c_{r}=\left(-E_{0} \ln U / m_{C u}\right)^{1 / 2}
$$

$32 \mathrm{Cu}$ 原子の揄送と表面付䓓 ターゲットから 放出された $\mathrm{Cu}$ 原子はチャンバ内のイオン, 原子, 分 子と衝突しながら輸送される. 圧力 $2.7 \mathrm{~Pa}$ ，温度 298 $\mathrm{K}$ の $\mathrm{Ar}$ の密度は $6.6 \times 10^{14} \mathrm{~cm}^{-3}$ である. これに対して $\mathrm{Ar}^{+}$イオン密度は $\$ 3.3$ のプラズマシミュレーション から $1.0 \times 10^{11} \mathrm{~cm}^{-3}$, 堆積レートから求めた $\mathrm{Cu}$ 原子と Cu イオン（以後これらを合わせて Cu 粒子と呼ぶ）

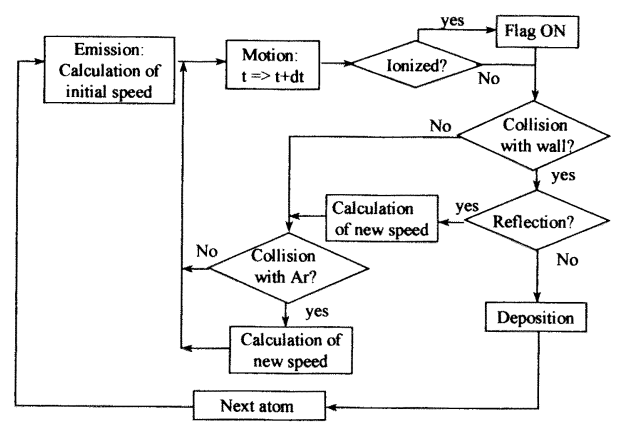

* $\mathrm{Cu}$ and $\mathrm{Ar}$ atoms are assumed to be ridid spheres in calculating collisions.

Fig.5 Flowchart for test-particle Monte Carlo method

の密度は $2.7 \times 10^{12} \mathrm{~cm}^{-3}$ で非常に小さい. また準安定 $\mathrm{Ar}^{*}$ の密度も $\mathrm{Ar}$ 原子と比較してきわめて小さい(2). し たがってチャンバ内部の粒子はほとんどが $\mathrm{Ar}$ 原子と 考えられる.これから Cu粒子は Ar原子とだけ衝突す ると仮定でき，テスト粒子モンテカルロ法が可能とな る. このテスト粒子モンテカルロ法の計算フローを図 5に示す.ここでは $\mathrm{Cu}$ 原子と $\mathrm{Ar}$ 原子は剛体球とし た. また, $\mathrm{Ar}$ 原子はチャンハ壁の設定温度 $\left(25^{\circ} \mathrm{C}\right)$ で 熱運動をしていると仮定し，Arの速度分布は $298 \mathrm{~K} の$ マックスウェル分布であるとした.

まず，ターゲットから放出される一個の $\mathrm{Cu}$ 原子を 考える.この原子は(1)〜 (4)式で求めた速度で移動す る. この速度から微少時間 $d t$ 秒後の $\mathrm{Cu}$ 原子の位置 が求まる. $\mathrm{Cu}$ 原子が $\mathrm{Ar}$ 原子，または壁面に衝突した か判定し, 衝突していない場合はさらに $d t$ 秒時間を 進める. $\mathrm{Cu}$ 原子と $\mathrm{Ar}$ 原子との衝突は次の条件を満た した時に起きる.

$$
U<P_{C u}
$$

ここで $U$ は一様乱数， $P_{C u}$ は散乱確率である.

$$
P_{C u}=n_{A r} \bar{g} \sigma_{T} \Delta t
$$

ここで $n_{A r}$ は $\mathrm{Ar}$ の数密度, $\Delta t$ はタイムステップ, $\overline{\mathbf{g}}$ は平均相対速度, $\sigma_{T}$ は全衝突断面積である. $\overline{\mathbf{g}}$ と $\sigma_{T}$ は式(7) (8)で与えられる(20).

$$
\bar{g}=\sqrt{2 R_{A r} T_{A r}}\left[\left(\eta+\frac{1}{2 \eta}\right) \operatorname{erf} \eta+\pi^{1 / 2} \exp \left(-\eta^{2}\right)\right]
$$


ここで $R_{A r}=k_{B} / m_{A r}, \eta=c_{C u} / \sqrt{2 R_{A r} T_{A r}}$, $R_{A r}$ は $\mathrm{Ar}$ のガス定数, $k_{B}$ はボルツマン定数, $m_{A r}$ は $\mathrm{Ar}$ 原子の質量, $c_{C u}$ は $\mathrm{Cu}$ 原子の速度, $T_{A r}$ は $\mathrm{Ar}$ ガス温度, erf $\eta$ は誤差関数である.

$$
\sigma_{T}=\pi\left[\left(d_{A r}+d_{C u}\right) / 2\right]^{2}
$$

ここで $d_{A r}$ は $\mathrm{Ar}$ 原子直径で $3.64 \times 10^{10} \mathrm{~m}$ である(23). $d_{C u}$ は $\mathrm{Cu}$ 原子直径であり $\mathrm{Ar}$ および $\mathrm{Kr}$ の原子番号と 原子直径の比から $3.96 \times 10^{-10} \mathrm{~m}$ と求めた ${ }^{(5)(23)}$.

$\mathrm{Ar}$ 原子と衝突した場合は衝突後の Cu原子の速度 と方向を計算し,$d t$ 秒時間を進める. 壁での衝突 判定は， $d t$ において Cu原子が壁面を通過したか で判定する. 壁に衝突した場合は壁面に付着したか 反射したかを判定する. Cu原子の付着確率はこれ までの測定より $93 \%$ とした ${ }^{(17)} . \mathrm{Cu}^{+}$イオンの付着確 率に対しては, MD(MolecularDynamics)の計算から高 速な $\mathrm{Cu}$ 粒子がウエ八垂線から $30^{\circ}$ 以上の角度で入 射した場合, 付着確率は低下寸るという報告 ${ }^{(24)}$ が ある.しかし $\mathrm{Cu}^{+} イ$ オンはシース内の電界によって ウエハに対し垂直に加速されるため, そのほとんど がウエ八表面や穴底に垂直に入射する. 穴側面に $\mathrm{Cu}^{+}$イオンが入射する可能性は角度的に低い。この ため, 本論文では $\mathrm{Cu}^{+}$イオンの付着確率も， $\mathrm{Cu}$ 原子 と同じ $93 \%$ と簡略化した. 入射角度依存性に関し ては第 2 報で詳細に行う.

反射した場合は衝突後の $\mathrm{Cu}$ の速度と方向を計算 し, 時間を $d t$ 進める. この時の反射される $\mathrm{Cu}$ は, 室温 $25^{\circ} \mathrm{C}$ のックスウェル分布とした. 壁面に付 着した場合は付着位置を記録し,このCu原子につ いての計算を終了する.

\section{3 プラスマシミュレーション イオン化スパ} ッタはスパッタ原子を電離し，バイアスでウエハに 引き込むことで埋め込み性を高めている. ターゲッ トから放出された Cu原子をイオン化する ICP-Coil

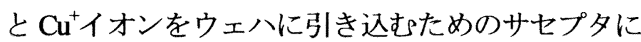
接続された RF 電源に対し, 円筒座標のプラズマシ ミュレーションを行った. プラズマシミュレーショ ンへの入力条件としては, ICP-CoilへのRFパワー $100 \mathrm{~W}$ ，サセプタの RF パワー $100 \mathrm{~W}$ とした。 また, 計算に用いた物性值として, チャンバ構成材料 $\mathrm{Al}$ の比透磁率 1.0, 石英チューブの比誘電率 3.9 を用い た. プラズマシミュレーションから, ICP-Coil とサ セプタの RF電源により生成されるプラズマの電子 密度, 電子温度, およびプラズマポテンシャルを求め
る. プラズマシミュレーションはCRC総合研究所の NeptuneFlidを用いた. このソフトは流体モデル(の)を用 いており, 計算は以下の $(9) 〜(10)$ 式を用いている.

$$
\begin{aligned}
& \frac{\partial n_{(e, i)}}{\partial t}+\nabla \cdot J_{(e, i)}=r_{i o n} N_{g a s} n_{e} \quad \ldots . \\
& J_{(e, i)}=-\mu_{(e, i)} n_{(e, i)} E-\nabla\left(D_{(e, i)} n_{(e, i)}\right)
\end{aligned}
$$

ここで, $n_{e}$ は電子密度, $n_{(e, i)}$ は電子または正イオン の密度, $J_{(e, i)}$ は電子または正イオンのフラックス, $r_{i o n}$ はイオン化の反応定数, $N_{g a s}$ は中性ガス密度, $\mu_{(e, i)}$ はイオンまたは電子の移動度, $E$ は電界, $D_{(e, i)}$ は電子またはイオンの㹡散保数である.

プラズマシミュレーションではプラズマ生成の主要 因となる以下の反志を考慮した.

$$
\begin{aligned}
& \mathrm{Ar}+\mathrm{e} \rightarrow \mathrm{Ar}^{+}+2 \mathrm{e} \quad \text { (イオン化) } \\
& \mathrm{Ar}+\mathrm{e} \rightarrow \mathrm{Ar}^{*}+\mathrm{e} \quad \text { (電子励起) } \\
& \mathrm{Ar}^{+}+\mathrm{Ar} \rightarrow \mathrm{Ar}+\mathrm{Ar}^{+} \text {(電荷交換) }
\end{aligned}
$$

ここで, 各反応の衝突断面積には文献 ${ }^{(20)}$ で報告 されている值を用いた. イオン化, 電子励起, 電荷 交換の反応定数は, この衝突断面積からボルツマン 方程式を解き, 電子温度に対する值としで(2)

Neptune/Fluid 中で計算される. また，イオンと電子 の移動度は $7.44 \times 10^{4}, \quad 1.5 \times 10^{2} \mathrm{~cm}^{2} / \mathrm{s}$, イオンと電 子の拡散係数は $3.8 \times 10^{4}, 1.5 \times 10^{17} \mathrm{~cm}^{2} / \mathrm{Vs}$ とした. この計算により, 装置中心付近の電子密度は $1.0 \times$ $10^{11} \mathrm{~cm}^{-3}$, プラズマポテンシャルは $19 \mathrm{~V}$, 電子温度 $2.0 \mathrm{eV}$, ウエハの自己バイアス電王は- $62 \mathrm{~V}$ が求まっ た. プラズマシミュレーションで, ウェハ中心と端 でこれらの值を比較した結果, 周辺での低下量はい ずれも $10 \%$ 以下であった.このため, 以下の議論 では, 電子密度, プラズマポテンシャル, 電子温度 は一定と近似し, 装置中央の值を用いた。

$3.4 \mathrm{Cu}$ 原子の重噰と $\mathrm{Cu}^{+}$イオンの再結合 イオ ン化スパッタ装置ではCu原子はチャンバ内を輸送さ れる間に, その一部は(14)式のように電離して $\mathrm{Cu}^{+} イ$ オンとなる.

$$
\left.\mathrm{Cu}+\mathrm{e} \rightarrow \mathrm{Cu}^{+}+2 \mathrm{e} \text { (イオン化 }\right)
$$


この確率 $P$ ，を求める.

$$
P_{i}=r_{C u} \cdot n_{e} \cdot d t
$$

ここで， $P_{i}$ はタイムステップあたりのイオン化確率, $n_{e}$ はプラズマシミュレーションで求まった電子密度 $1.0 \times 10^{11} \mathrm{~cm}^{-3}, d t$ はタイムステップである. $r_{C u}$ は $\mathrm{Cu}^{+}$ イオン化の反応定数で, $\mathrm{Cu}$ の電離衝突断面積 $\sigma(\varepsilon)$ とマクスウェル分布 $\chi(\varepsilon)$ から以下のように求めた(27).

$$
\chi(\varepsilon)=\frac{2}{\sqrt{\pi}}\left(k_{B} T_{e}\right)^{-\frac{3}{2}} \sqrt{\varepsilon} e^{-\frac{\varepsilon}{k_{B} T_{e}}}
$$

ここで， $\varepsilon$ は電子の運動エネルギー， $e$ は素電荷で ある. 反忍レート $r_{C u}$ は,

$$
r_{\text {(и }}\left(T_{e}\right)=\int \chi(\varepsilon) \sqrt{2 \varepsilon / m_{e}} \sigma(\varepsilon) d \varepsilon
$$

ここで, $m_{e}$ は電子の質量である. 電離衝突断面積 $\sigma(\varepsilon)$ は文献 ${ }^{(2)}$ 上り求めた. プラズマシミュレーショ ンから求まった $T_{e}=2 \mathrm{eV}$ を式(17)に代入して, $r_{C u}=1.01 \times 10^{-9} \mathrm{~cm}^{3} / \mathrm{s}$ を得た.

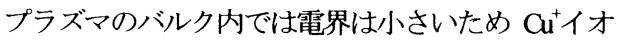
ンに電気的な力はほとんど働かない.このため $\mathrm{Cu}^{+}$イ オンは 傆子と同じ挙動をすると仮定した.

$\mathrm{Cu}^{+}$イオンの消滅原因には主に以下が考えられる(29).

$$
\begin{aligned}
& \mathrm{Cu}^{+}+\mathrm{Ar} \rightarrow \mathrm{Cu}+\mathrm{Ar}^{+} \text {(電荷交換) } \\
& \mathrm{Cu}^{+}+\mathrm{e} \rightarrow \mathrm{Cu}+\mathrm{h} v \quad \text { (放射再結合) } \\
& \mathrm{Cu}^{+}+\mathrm{e} \rightarrow \mathrm{Cu} \quad \text { (直接再結合) } \\
& \mathrm{Cu}^{+}+\mathrm{e}+\mathrm{Ar} \rightarrow \mathrm{Cu}+\mathrm{Ar} \\
& \text { (Ar，電子との三体衝突) } \\
& \mathrm{Cu}^{+}+\mathrm{e}+\mathrm{e} \rightarrow \mathrm{Cu}+\mathrm{e} \\
& \text { (電子との三体衝突) } \\
& \mathrm{Cu}^{+}+\text {Wall } \rightarrow \mathrm{Cu}+\text { Wall }
\end{aligned}
$$

このうち(18)の電荷交換においては, $\mathrm{Cu}$ の電離電圧 の䦨値が約 $8 \mathrm{eV}^{(28)}$ に対し $\mathrm{Ar}$ の閾值が $15.75 \mathrm{eV}^{(21)}$ であ り約 2 倍も大きいため, この反応は起こらない(30).
次に(19)を例にして Cu+イオンが再結合するまで

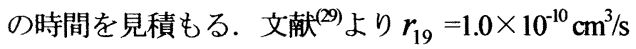
以下となり， 1 個の $\mathrm{Cu}^{+}$イオンが再結合するまでの 時間 $t_{19}$ を求めると,

$$
t_{19}=\frac{1}{r_{19} \times[e]}=0.1 \mathrm{sec} \text { 以上 }
$$

ここで, [e]は電子密度 $1.0 \times 10^{11} \mathrm{~cm}^{-3}$ である. 同様に して $t_{20 \sim 22}$ を見積もるといずれも $1(\mathrm{sec})$ 以上となる (2)(30).

一方，(23)Cu+イオンの壁面への衝突を考える. プ

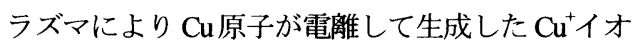
ンがウエハ人衝突するまでの平均時間 $t_{23}$ をシミュ レーションで求めたところ,

$$
t_{23}=0.0032 \mathrm{sec}
$$

となり, $t_{19 \sim 22}$ と比較して圧倒的に短い.これから $\mathrm{Cu}^{+}$イオンの消㓕は壁面・ウエハへの衝突時のみと 仮定した。

これらの計算により, ウエハ近傍でのCuのイオ ン化率 ( $\mathrm{Cu}^{+}$イオンの密度/Cu粒子の密度) は $34 \%$ あ゙あと求まった.

3.5 シースによるCu+イオンの加速 シース内で は, シース電位により $\mathrm{Cu}^{+}$イオンは大きな力を受け る. 今回用いたプラズマシミュレーションは流体コ ードであるため, シース厚を正確には計算できない， そこで, シース厚 $d$ がデバイ長の 5 倍であるとい う報告をもとに計算した ${ }^{(31)}$. デバイ長 $\lambda_{D}$ は $^{(21)}$,

$$
\lambda_{D}=\left(\frac{\varepsilon_{0} k_{B} T_{e}}{n_{e} e^{2}}\right)^{1 / 2}=0.0332 \mathrm{~mm}
$$

ここで， $\varepsilon_{0}$ は真空中の誘電率である.これから， $d=0.0332 \times 5=0.166 \mathrm{~mm}$ となる. 一方 $\mathrm{Cu}$ 原子の平均自 由行程 $\lambda_{f}$ は, 圧力 $2.7 \mathrm{~Pa}$ より, $24 \mathrm{~mm}$ 程度となるこ とから, シース内での Cu と Arの衝突は少ないと考え られる. そこで，ウエハに入射るる $\mathrm{Cu}^{+}$ウオンにはウ エハに垂直な速度成分が加わるとした. プラズマとウ エ八の電位差はプラズマシミュレーションから $81 \mathrm{~V}$ 
と求まるため, $81 \mathrm{eV}$ の垂直方向の運動エネルギーを 加えた.

$3.6 \mathrm{Cu}$ 原子・イオンのウエハへの付着ウエハ 表面に堆積寸る膨大な数の $\mathrm{Cu}$ 原子すべてを計算する のは現実的ではない，簡略化による計算時間短縮およ びメモリ容量の節約が必要になる.今回の計算で行っ た簡略化手法を図6に示寸。

(1)半導体の穴の数は膨大なものになるため, その全 てを一度に計算することは不可能である。 そこで 中心の1穴を代表として解く. 中心から半径 $10 \mathrm{~mm}$ の範用はウエハ全体と比べて比較的狭い領域であ るため $\mathrm{u}$ 原子およびイオンの速度の分布は半径に よらず同じであると仮定し，この部分に輸送され た Ou+イオンおよび原子はすべて代表穴に堆積する とした.

(2)代表穴の内部空間（直径 $03 \mu \mathrm{m}$, 哚さ $1.0 \mu \mathrm{m}$ ) は 円筒であると仮定した. 堆積は 2 次元半断面で計 算を行った. ただし本論文においては写真と比較 するために，鏡像も表示して全断面としている.

(3)実際には堆積させる $\mathrm{Cu}$ の近接原子間距離は 0.2556 $\mathrm{nm}$ であるが(22)，シミュレーションでは面を 1 辺 $0.25 \mathrm{~nm}$ の正方形の面素の集合と考光，面素に Cu原 子が 1 個入った時に壁に垂直に膜が $0.25 \mathrm{~nm}$ 成長す ると仮定した. 一方， Ou 原子が面素と接触し反射 する場合は，面素の接触点加面素面に対し余弦 則で $\mathrm{Cu}$ 原子が反射するとした。 この時の $\mathrm{Cu}$ の運 動エネルギーは, 室温 $25^{\circ} \mathrm{C}$ のックスウェル分布 であるとした。

\section{4. 実験結果との比較}

4.1 イオン化の有無による差異 図7 に穴への Cu成膜の SEM 像を示す。なお，SEM写真用のサン プルはウェハを割って作成しているが，Cuは延性

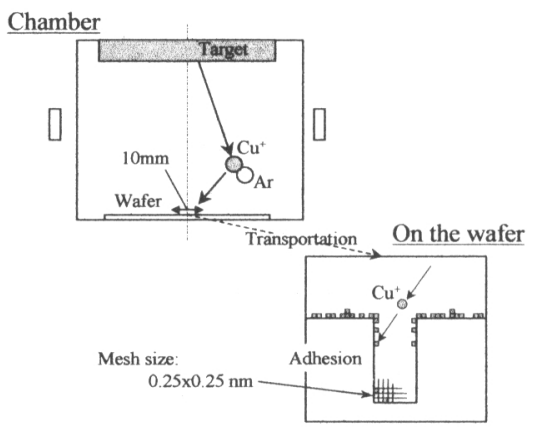

Fig.6 Deposition simulation
が高いため膜密度の高いウエ八上平坦部では膜が延 びて変形する．このため, ウエ八上平坦部の撮影は 行っていない，また，変形によって穴の入口部に広 がったような線ができている。しかしながら，実際 の Cu成膜面は図 7 の破線で示したように，この線 の内側に薄く見える線であることを，TEM写真に より確認している. 図8 (a)にCu原子のイオン化を 考慮していない場合のシミュレーション結果を，図 8(b)に本論文のイオン化を考慮に入れたシミュレ ーション結果を示す。これから，イオン化を考慮し ていないシミュレーションでは，底部に $\mathrm{Cu}$ がほと んど認められないが，イオン化を考慮したシミュレ ーションでは底部に SEM 像と同程度の Cuの堆積が ある等，形状をほぼ再現していることがわかる。な お，底部での唯積がシミュレーションでは上に凸形 状なのに対して SEM写真で平坦なのは, 付着時の 粒子移動を考慮していないためで(13)，これについて は第 2 報で報告する。

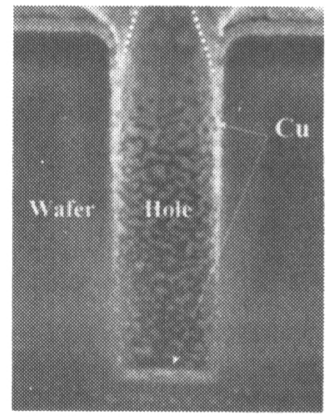

Fig.7 Deposition (SEM Image)

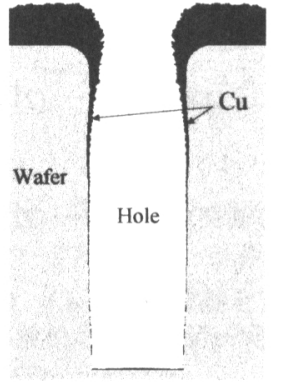

(a) Non-lonization

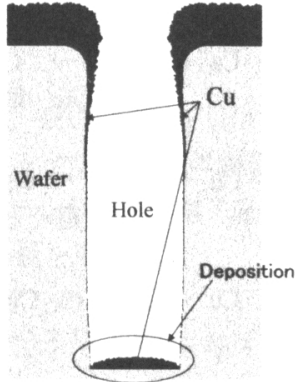

(b) Ionization rate : $34 \%$ 


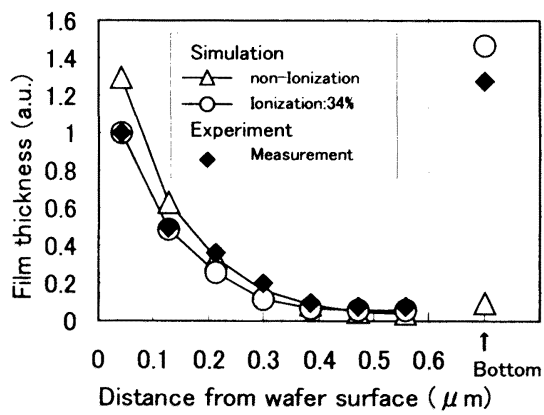

Fig.9 Comparison of simulated and measured thickness

図 9 に穴内面での $\mathrm{Cu}$ 膜厚のシミュレーション結果 と実測の比較を示す.シミュレーションはイオン化の 有無の 2 種を示す．横軸はウエ八表面から唄壁に沿っ て測った距離，縦軸はその点の膜厚である．グラフの 右に穴底の膜厚をプロットした。

これからイオン化を考虑したシミュレーション結果 は, SEM 像の実測值を精度良く再現していることが わかる. 一方イオン化を考慮していないシミュレーシ ヨン結果は, ウエハ表面に近い側壁において実測值よ り膜厚が厚く，穴底に扑て実測値より大幅に薄い.

\section{2 穴内经と成莫形状の閏係 パターンの微細} 化によってイオン化スパッタによる成膜形状がどのよ うに変化するかを知ることは本シミュレーションの 目的の一つである. そこで穴内径を変えた場合につい てシミュレーションを行った. 図 10 に 3 種類の径の

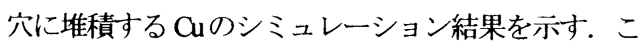
こで，シミュレーション上の成膜時間は，実験での 成膜時間に対応させて 30 分とした. さらに Guシ ド層成膜で重要になる敗壁のウォールカバレッジ $W_{c}$ の計算結果および実測值を図 11 に示す.ただし,

$$
W_{c}=\frac{d_{50 \%}}{d_{\text {surface }}}
$$

ここで， $d_{50 \%}$ はウエ八表面と穴底の中間点での側 壁の $\mathrm{Cu}$ 膜厚, $d_{\text {surface }}$ はウエハ表面の膜厚であり, 実験では電気抵抗を測定することで求めた。これより， 穴径が縮小するにつれ側壁のウォールカバレッジが悪 化していく傾向が，シミュレーションにより再現され た。サイドカバレッジの絶対值と低下割合

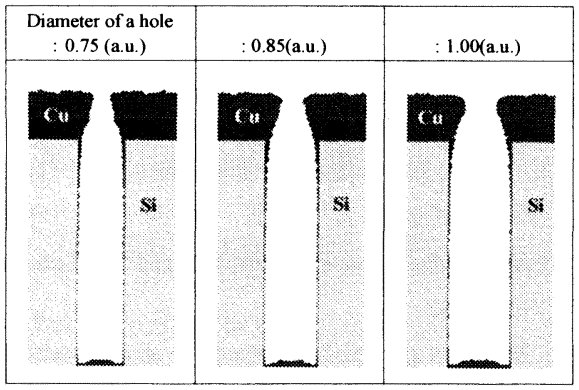

Fig.10 The embedding characteristic to a hole

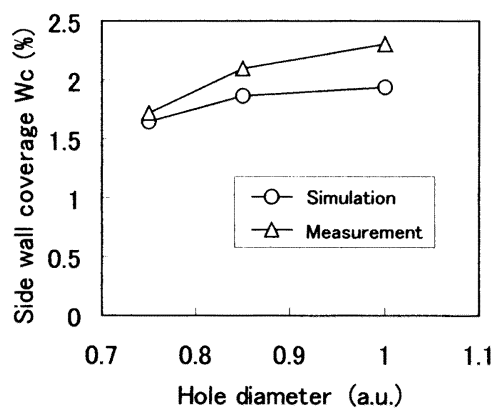

Fig.11 Comparison of simulated and measured thickness

までを再現するためには，高いエネルギーを持つ $\mathrm{Cu}^{+}$ イオンの付着確率の入射角依存性を考慮したより高精 度なモデリングが必要である ${ }^{(24)}$. さらに $\$ 4.1$ で述べ た付着時の $\mathrm{Cu}$ 原子の移動, 高速イオン付着確率の入 射角依存性など表面反応の詳細な検討は第 2 報で報告 する.

\section{5. 結 言}

$\mathrm{Cu}$ 原子のイオン化を考虑することにより $\mathrm{Gu}$ のイオ ン化スパッタ装置のシミュレーションを行う手法を開 発した.この結果実測の形状結果と良く一致する計算 結果が得られた. さらにこの方法を用いて, シード層 成膜上重要な側壁のウォールカバレッジの穴径依存性 を求めた.このシミュレータにより埋め込み性能の高 い装置の開発やプロセス条件の最適化が可能となると 考えられる.

本研究を行うにあたり, 株式会社東芝の片岡好則氏, 加納正明氏から貴重なご助言を頂いた. 記して謝意を 表する. 


\section{文 嗝}

（1）新宮原正三他編，Cu 配線技術の最新の展開, (1998), 3-7, 株式会社リアライズ社

（2）吉川公魔: ULSI の微細化と多層配線技術への課題応 用物理, 68(1999)，1215-1225

(3) S. M. Rossnagel and J. Hopwood: Appl. Phys. Lett. 63, (1993), 3285

(4) S. M. Rossnagel and J. Hopwood: J. Vac. Sci. Technol. B 12, (1994), 449-453

(5) T. Motohiro et al: Thin Solid Films, 112, (1984), 161173

(6) V.V.Serikov et al: J. Vac. Sci. Technol., A16, (1996), 3108-3123

(7) M. Tuda et al: Jpn. J. Appl. Phys., 33, (1994), 44734477

(8) I.A.Blech et al: J. Vac. Sci. Technol. Vol.15,(1978),13

(9) W.G.Oldham et al:IEEE Trans. on Electron Devices, Vol.ED-27, No.8(1980), 1455

(10) H.P.Bader and M.A.Lardon:J.Vac.Sci.Technol. A3(6), (1985), 2167

（11）小泉浩治: 日本機械学会第 4 回計算力学講演会講演論 文集 No.910-79, (1991), 213

(12) S.K.Dew et al: J. Vac. Sci. Tecnol. A9(3), (1991), 519

（13）南部健一, 本多尚久: 機論 B59 巻 557 号,(1993), 93

(14) 池川正人, 小林淳一: 機論 B59 巻 567 号,(1993), 3365

（15）宮崎則幸, 白鳥正樹共編, 計算力学IV, (1999) 71, 養賢 堂

(16) S.Desa et al: J.Vac.Sci.Technol. A17(4), (1999), 1926

(17) O. Yamazaki et al: Jpn. J. Appl. Phys. 41, (2002), 12301234

(18) S.Hamaguchi and S.M.Rossnagel: J.Vac.SciTechnol. B13(2), (1995), 183

(19) S.Hamaguchi and S.M.Rossnagel: J.Vac.Sci.Technol B14(4), (1996), 2603

（20）日本機械学会編, 原子・分子モデルを用いる数值シミ ユレーション, (1996), 108-110, コロナ社

(21) 堤井信力, プラズマ基礎工学増補版, (1995), 3-5, 9, 28, 42-47,269, 内田老鶴圃

（22）金原梷, スパタリング現象, (1984), 37-42, 東京大学出 版会

(23) 日本真空協会編, 第 33 回真空夏期大学テキスト, (1993), 10

(24) J.D.Kress et al: J. Vac. Sci. Technol, A17, (1999),2819 2825

(25) E.Suetomi et al: Phys. Commun., 125, (2000), 60
(26) 電気学会編: 電気学会技法, 691, (1998), 69

(27) M.Meeks et al: J. Vac. Sci. Technol, A16, (1995), 544

(28) 日本学術振興会プラズマ材料科学第 153 委員会, プラ ズマ材料科学ハンドブック,(1992), 753, オーム社

(29) 電気学会, 改訂新版放電ハンドブック,(1974), 44, オー 么社

(30) M. A. Lieberman and A.J.Lichtenberg, PRINCIPLES OF PLASMA DISCHARGES AND MATERIALS PROCESSING, (1994), 73-77, 256, Wiley-interscience Publication

(31) H.S.Han and P.McVittle: J. Vac. Sci Technol, B13, (1995), 1893

（32）小原嗣朗, 金属材料概論（增補版），(1991）, 280-281, 朝倉書店

（33）KDLeaver,金属の薄膜, (1975),27, 共立出版株式会社 